Monkey business

\section{Bolivia asks for animals back}

Washington

THE government of Bolivia is demanding the return of 361 owl and squirrel monkeys exported to the United States last month for use in the development of a malaria vaccine. The animals, the first of a lot of 600 , were exported under a special ministerial exemption to Bolivia's existing ban on the export of fauna and are now under quarantine in Miami. Last week the ministerial exemption was annulled and the rest of the shipment is unlikely to leave Bolivia.

The animals were imported by Worldwide Primates Inc. of Miami, run by animal dealer millionaire Matthew Block, and were to have been distributed to more than 14 US institutions supporting malaria research. The animals are not considered seriously at risk of extinction, although it is argued that there has been no adequate census of the animals and that it would be possible to use captive-bred animals for the research.

The affair led to frank disagreement between the State Department, which has supported Bolivia's efforts to reduce illegal animal exports, and the US Agency for International Development (AID), which coordinates malaria research. Two years ago, Bolivia banned the export of all fauna (although enforcement is generally considered lax) and so the State Department declared its opposition to the deal. Bolivia is also a signatory of CITES, the Convention on International Trade in Endangered Species.

Squirrel monkeys and owl monkeys (Saimiri scioureous boliviensis and Actus trivirgatusson) are listed in Appendix 2 of CITES, which means they are considered threatened but not "endangered". US laws permit the import of Appendix 2 animals with proper documentation.

The proposal to export the animals to the United States was apparently made by Bolivian scientists at a conference on malaria in Florida last autumn, and the Bolivian government agreed. State Department officials were concerned about the setting of a precedent, but backed down when it became clear that Worldwide had secured a government exemption. Dr Kenneth Bart of AID's health office later criticized the State Department for "inappropriately" describing the species as "endangered".

There has been a worldwide resurgence of malaria in the past few years, primarily because of the drug resistance of malaria parasites and insecticide resistance in the mosquito vectors. The disease causes $2-3$ million deaths each year, mainly among young children. There has been significant progress towards vaccines in recent years thanks to genetic engineering, but the dif-

\section{AIDS}

ficulty of obtaining non-human primates for testing (required by the Food and Drug Administration before human volunteer trials can begin) has become a major bottleneck. AID has supported a network of laboratories working towards a vaccine for 15 years.

The Bolivian Embassy in Washington will offer no explanation for the exemption or its withdrawal; AID officials blame hysteria in the Bolivian press and political machinations by opponents of the government.

The details of how the ministerial resolution allowing the export (no. 347/85) was obtained are intriguing. The resolution names as Worldwide Primates' representative in Bolivia a company called Altros Internacional, although the CITES export certification names Aves Import as the exporter. The animals already in the United States (341 squirrel monkeys and 20 owl monkeys) have a declared value of $\$ 55,150$. The resolution reversing the earlier exemption is no. 45/86; it is unclear whether the animals (now the property of AID) will be returned to Bolivia to be released to their native habitat, as the government is demanding.

Officials in the Bolivian department of agriculture were initially introduced to close family relatives of Altros's owner by Gene Harris, a US travel agent; a US AID official certified that the animals were to be used for bona fide medical research and would later go to breeding colonies. Later, following highly critical coverage of the affair in the Bolivian newspaper Ultima Hora and (ungrounded) suggestions that the animals were destined for pet shops, Altros decided to have nothing more to do with the deal, and Aves solicited and received the CITES export document. Altros then brought a civil suit against Block and is said to be seeking compensation for having its good name besmirched; however, an arrest warrant was put out for Block, and his passport was confiscated. Block has nevertheless managed to return to the United States. The US State Department is uncommunicative, saying the United States takes no formal position on either the exemption or its withdrawal.

\title{
Japan screens donated blood
}

Tokyo

JAPAN is waking up to the fact that it is not immune from acquired immune deficiency syndrome (AIDS). Japan's Health and Welfare Ministry has rushed to implement a programme to screen a large proportion of the nation's blood donors, and an emergency grant has been awarded to develop new diagnostic tests for AIDS. These developments come close on the heels of approval of the import of an AIDS antibody test kit manufactured by Abbot Laboratories of the United States and confirmation of three more cases of AIDS in Japan, bringing the total to fourteen.

Japan's Red Cross will test the blood of one million donors in Tokyo and Osaka over a period of one year from 17 February, thereby screening more than 10 per cent of the 8 million expected donations. As recently as November, the Health and Welfare Ministry had stated that mandatory screening of blood donors for AIDS was unnecessary and that the estimated cost, Y10,000 million (about $£ 38$ million), was prohibitively high (see Nature 318, $306 ; 1985$ ), but increased media coverage made it more urgent to allay public concern.

Pamphlets have been distributed by the Health and Welfare Ministry reassuring the public that if they live a "normal" life they have almost no chance of catching AIDS, and prefectural and municipal health officials were recently given a semi- nar on the disease. But ignorance is still rife, and the conviction lingers that AIDS is somehow a "foreign" disease.

A dial-for-AIDS-advice service in Tokyo, which earlier last year was receiving only a few calls per month, is now inundated with questions centred on the fear that contact with foreigners may cause infection. The report that one of the latest AIDS sufferers, a foreigner, associated with Japanese men because he thought they were free of AIDS will no doubt only add fuel to such suspicions.

The Red Cross will use an enzymelinked immunosorbent assay (ELISA) antibody test kit supplied by Dynabbot, the Japanese subsidiary of Abbot Laboratories, for the block screening programme. It was announced last week, however, that an emergency grant of Y40 million has been awarded by Japan's Science and Technology Agency to two research teams at the Health and Welfare Ministry's Health and Medical Affairs Bureau and the National Institute of Health to develop more reliable AIDS tests.

In addition to the testing of one million donors, Y50 million has been put aside this year by the Japanese government for blood screening, but the funds allocated for AIDS research in Japan pall to insignificance compared with the more than $\$ 300$ million (about Y55,000 million) expected to be spent by the US Public Health Service on AIDS research this year.
David Swinbanks 